\title{
Sulfonylurea-induced inhibition of glucagon secretion from the perfused rat pancreas: evidence for a direct, non-paracrine effect
}

\author{
C.-G.Östenson, A. Nylén, V.Grill, M. Gutniak and S. Efendić \\ Department of Endocrinology, Karolinska Hospital, Stockholm, Sweden
}

\begin{abstract}
Summary. The effects of sulfonylurea on glucagon secretion were characterized in the perfused rat pancreas using glibenclamide $(1 \mu \mathrm{g} / \mathrm{ml})$ or tolazamide $(10 \mu \mathrm{g} / \mathrm{ml})$ in the presence of $3.3 \mathrm{mmol} / 1$ glucose. Glucagon release, which was unaffected by glibenclamide at $2.75 \mathrm{mmol} / 1$ calcium, was suppressed at 1.19 and $0.64 \mathrm{mmol} / 1$ but transiently stimulated at $0.25 \mathrm{mmol} / 1$ extracellular calcium. The insulinogenic effect of giibenclamide at 0.64 and $0.25 \mathrm{mmol} / \mathrm{l}$ calcium was enhanced by $35 \%$ and $89 \%$, respectively, compared to the response at $2.75 \mathrm{mmol} / 1$ calcium. The stimulatory effect of the compound on somatostatin secretion, however, was lost at the lower calcium levels. The effects of tolazamide at 2.75 and $0.64 \mathrm{mmol} / 1$ calcium mimicked those of glibenclamide, thus indicating that our results with the latter compound may be representative for all sulfonylureas. In pancreata from insulin-deficient alloxan-
\end{abstract}

diabetic rats, glibenclamide completely lost its inhibitory effect on glucagon release at $0.64 \mathrm{mmol} / 1$ calcium. Inhibition was not restored by adding insulin $(25 \mathrm{U} / 1)$ to the perfusate. However, when diabetic rats had been treated with insulin for 6-7 days, glibenclamide suppressed glucagon release at low calcium levels in the absence of stimulated insulin and somatostatin release. It is concluded that, at low calcium concentrations, sulfonylureas suppress glucagon secretion by a direct action on the A cell and not through paracrine interactions by insulin and somatostatin. Prolonged insulin deficiency impairs the sulfonylurea action on glucagon secretion.

Key words: Perfused rat pancreas; sulfonylurea; insulin; glucagon; somatostatin; alloxan-diabetes
It is well established that sulfonylureas stimulate the pancreatic secretion of insulin and somatostatin [1-3]. Glucagon release, on the other hand, is reportedly either unaffected [4-6], stimulated [7, 8], inhibited [9-11], or dually stimulated-inhibited $[8,12]$ by this group of compounds. These conflicting results probably originate from the use of different experimental conditions. The glucagon response thus appears to depend on the species studied and the type and concentration of sulfonylureas $[12,13]$, as well as on the concentration of ambient nutrients and electrolytes such as glucose, amino acids, calcium and potassium [3, 8, 12-17]. Since these factors also affect the interaction of sulfonylureas with the secretion of insulin and somatostatin, it has been repeatedly suggested that the effect of sulfonylureas on glucagon release is mainly determined by paracrine interactions between $B$ and D cells on one hand and the glucagon-producing A cell on the other hand $[3,12,15]$.

Studies in the isolated perfused rat pancreas have demonstrated that glucagon secretion, at physiological levels of glucose and calcium, is unaffected by gliben- clamide, a second generation sulfonylurea $[3,18]$. In the absence or near-absence of glucose [3] and in the pancreata isolated from fasted animals [18], however, the compound evoked a significant suppression of glucagon release. This effect was parallelled by enhanced somatostatin responses. In contrast, when glibenclamide was introduced concomittant with a low calcium level $(0.25 \mathrm{mmol} / \mathrm{l})$, the compound enhanced glucagon release while somatostatin release was abolished [17]. Taken together, these findings support the idea that the inhibitory effect of glibenclamide on the A cells is mediated by a paracrine effect of somatostatin $[3,15]$.

The aim of the present investigation was to further elucidate the nature of the effect by sulfonylurea on the glucagon-producing A cell. For this purpose, we have studied the glibenclamide-induced insulin-, glucagonand somatostatin-responses after imposing different levels of calcium in the perfused medium. Our initial results showed that, at moderately decreased calcium levels, glibenclamide inhibited glucagon release while somatostatin release was abolished. The effects of glibenclamide at $0.64 \mathrm{mmol} / 1$ calcium in pancreata iso- 
lated from insulin-deficient alloxan-diabetic rats were then investigated, since paracrine influences of $B$ and D cells on glucagon secretion seemed to be eliminated by the destruction of $B$ cells and the attenuation of $D$ cell response. In order to clarify whether the observations obtained with glibenclamide may be extended to other sulfonylureas, we also characterized the effects of a first generation sulfonylurea tolazamide at normal and reduced levels of calcium in the perfusate.

\section{Materials and methods}

\begin{abstract}
Animals
Male Sprague-Dawley rats (Anticimex, Solna, Sweden), weighing $200-250 \mathrm{~g}$ and fed ad libitum, were used. Experimental diabetes was induced in one series of rats by an intraperitoneal injection of alloxan monohydrate $(180 \mathrm{mg} / \mathrm{kg}$ body weight; Sigma, St. Louis, Mo, USA) dissolved in $0.5 \mathrm{ml}$ of ice-cold saline immediately before the injection. All diabetic rats were used for perfusion experiments two weeks after the alloxan treatment. One group of diabetic rats received one daily subcutaneous injection of heat-treated [19] ultralente insulin (6-10 U/ d; Novo, Bagsvaerd, Denmark) to achieve normoglycaemia during the last 6-7 days preceding perfusions. Blood glucose concentrations and body weights were monitored daily in each of the alloxan-diabetic rats.
\end{abstract}

\section{Perfusion of isolated pancreas}

All animals were anaesthetized by an intraperitoneal injection of pentobarbital ( $100 \mathrm{mg} / \mathrm{kg}$ body weight). Each pancreas was dissected free from adjacent tissues [20] and perfused by a cannula inserted into the abdominal aorta. The perfusion medium was not allowed to recirculate. Except for variations in calcium, it consisted of a Krebs-Henseleit bicarbonate buffer solution [21] containing $20 \mathrm{~g} / 1$ bovine plasma albumin (Sigma) and $3.3 \mathrm{mmol} / 1 \mathrm{D}$-glucose. Varying concentrations of calcium in different protocols were achieved by the addition of different amounts of $\mathrm{CaCl}_{2}$, resulting in total calcium concentrations of $0.25,0.64,1.19$ and $2.75 \mathrm{mmol} / \mathrm{l}$. Although calcium concentrations differed between experimental protocols, they were in no instance varied during the course of each experiment. All experiments included an initial 20 min equilibration period (during which the desired levels of calcium were already present), recorded in the Figures as $\min -20$ to zero. The period of equilibration was followed by a test period (recorded as min $0-20$ in the Figures) during which glibenclamide (1 mg/l; Hoechst AG, Frankfurt, FRG) or tolazamide $(10 \mathrm{mg} / 1$; Hoechst $A G$ ) was present in the perfusion medium. The sulfonylurea drugs were dissolved at concentrations of $0.5 \mathrm{mg} / \mathrm{ml}$ and $5 \mathrm{mg} / \mathrm{ml}$, respectively, in distilled water with addition of a small amount of $5 \mathrm{mmol} / 1 \mathrm{NaOH}$. Each experiment was terminated with a $10 \mathrm{~min}$ period (recorded as min 20-30 in the Figures) of perfusion with drug-free medium. In control experiments the pancreas was perfused throughout the experiment with a medium containing the appropriate calcium concentration but without the intermittent presence of drug during $\min 0-20$.

Some experiments were designed to test the effect of insulin in vitro in alloxan-diabetic rats. In these experiments regular insulin at a concentration of $24 \mathrm{U} / 1$ (Nordisk Insulin, Copenhagen, Denmark) was present in the perfusion medium throughout the experiments, i.e. from $\min -20$ to +30 .

The flow rate of perfusion medium was kept constant at $2.8 \mathrm{ml} /$ $\min$. No visible edema of the pancreas developed. At the intervals indicated in the Figures, samples of the perfusion medium were collected into ice-chilled tubes containing $1000 \mathrm{KIU}$ of aprotinine (Trasylol; Bayer, Leverkusen, FRG) and stored deep-frozen for subsequent radioimmunoassay of insulin [22], glucagon [23] and somatostatin [3].
After perfusions, pancreata from non-diabetic and diabetic animals were homogenized and extracted overnight at $+4{ }^{\circ} \mathrm{C}$ in acid ethanol $(70 \% \mathrm{w} / \mathrm{v})$ for determination of total pancreatic content of insulin, glucagon and somatostatin.

Statistical analysis. Significance testing was performed using Student's t-test for unpaired data. A $p$ value of 0.05 was considered statistically significant.

\section{Results}

\section{Effects of extracellular calcium concentrations on glibenclamide-induced hormone release}

Insulin. The insulin response to glibenclamide was similar at 2.75 and $1.19 \mathrm{mmol} / 1$ calcium in the perfusate (Fig.1, Table 1). At 0.64 and $0.25 \mathrm{mmol} / 1$ calcium, the first peak of insulin release (min $0-5$ ) was increased two-fold. Further, at the lowest calcium concentration the second phase of glibenclamide-induced release was enhanced by $75 \%$. At all calcium concentrations, insulin release was still elevated during the 10 -min period following the presence of glibenclamide. In control perfusions, where glibenclamide was absent throughout the experiments, no significant insulin response was detected at $2.75,0.64$ or $0.25 \mathrm{mmol} / 1$ calcium (Fig. 1).

Glucagon. The low basal release of glucagon was not significantly affected by glibenclamide at $2.75 \mathrm{mmol} / 1$ of calcium. When tested at $1.19 \mathrm{mmol} / 1$ and 0.64 mmol/1 of calcium, glibenclamide markedly and progressively suppressed glucagon release (Fig.1, Table 1). At these calcium concentrations the basal secretory rates were increased three- to five-fold as compared to basal secretion at $2.75 \mathrm{mmol} / \mathrm{l}$ of calcium. At the lowest calcium concentration $(0.25 \mathrm{mmol} / \mathrm{l})$ basal secretion rate was further increased. Glibenclamide, however, elicited a short-lived ( $5 \mathrm{~min}$ ) peak of glucagon release, followed by a modest decline in secretion rate. Control perfusions at $0.25 \mathrm{mmol} / 1$ calcium (without glibenclamide) revealed a similar decline in glucagon secretion (Fig.1), indicating that the decrement following the short-lived peak of glucagon is time- and not glibenclamide-dependent. In contrast, at $0.64 \mathrm{mmol} / 1$ calcium the decline in glucagon secretion as a function of perfusion time was significantly smaller $(-11482 \pm 2243 \mathrm{pg} /$ $20 \mathrm{~min}$ ) than the marked suppression induced by glibenclamide $(-22177 \pm 1698 \mathrm{pg} / 20 \mathrm{~min} ; n=6, p<0.01$; Fig.1).

Somatostatin. At $2.75 \mathrm{mmol} / 1$ of calcium, glibenclamide evoked a biphasic somatostatin response which amounted to a five-fold enhancement above the basal secretion (Fig.1, Table 1). The stimulated somatostatin secretion persisted for a least $10 \mathrm{~min}$ after omission of glibenclamide. When the calcium concentration was $1.19 \mathrm{mmol} / \mathrm{l}$ rather than $2.75 \mathrm{mmol} / \mathrm{l}$, glibenclamide-induced somatostatin release was inhibited by $77 \%$ 
$2.75 \mathrm{mmol} / \mathrm{l} \mathrm{Ca}$

$1.19 \mathrm{mmol} / \mathrm{I} \mathrm{Ca}$

$0.64 \mathrm{~m} \mathrm{~mol} / \mathrm{I} \mathrm{Ca}$

$0.25 \mathrm{mmol} / \mathrm{Ca}$
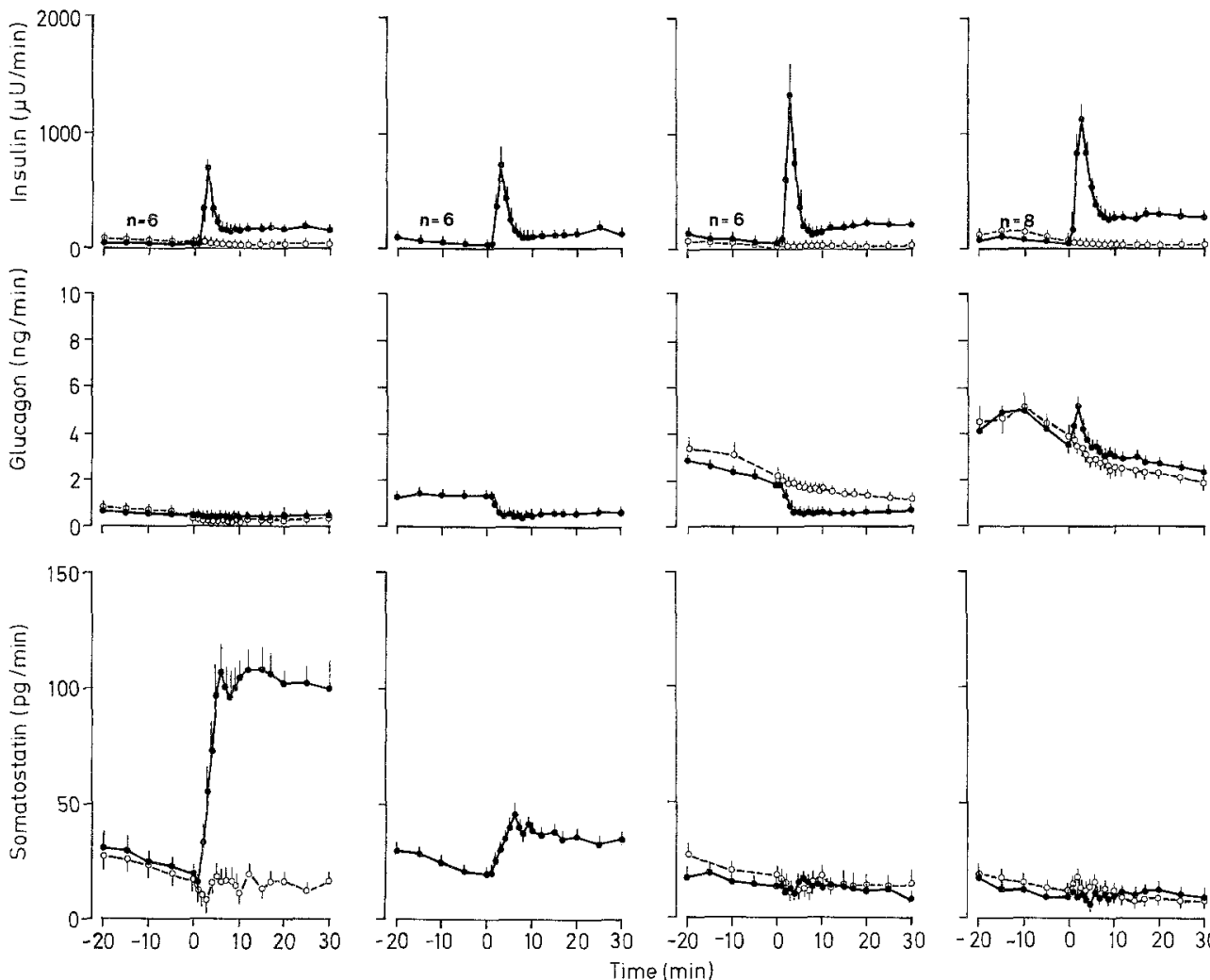
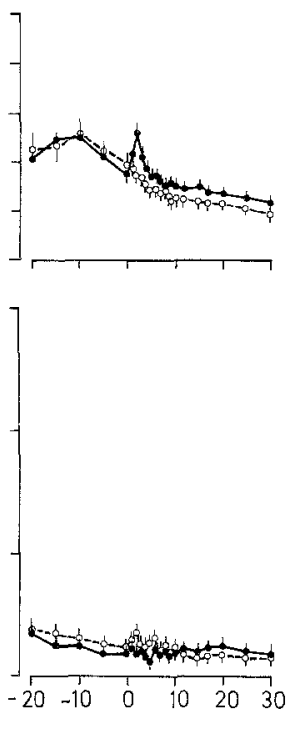

Fig. 1. Effects of different extracellular concentrations of calcium on pancreatic hormone responses to glibenclamide $(\longrightarrow)$. Calcium concentrations were kept constant throughout the experiments. Glibenclamide $(1 \mu \mathrm{g} / \mathrm{ml})$ was added during $\min 0-20$. Hormone release in control perfusions without glibenclamide is also included for calcium concentrations $2.75,0.64$ and $0.25 \mathrm{mmol} / \mathrm{l}(\mathrm{O}---\mathrm{O})$. Mean $\pm \mathrm{SEM}$ of the respective number of experiments indicated in the Figure
$(321 \pm 71 \mathrm{pg} / 20 \mathrm{~min}$ at $1.19 \mathrm{mmol} / 1$ vs. $1.405 \pm 137 \mathrm{pg} /$ $20 \mathrm{~min}$ at $2.75 \mathrm{mmol} / 1$ calcium; $p<0.001$ ). In experiments with $0.64 \mathrm{mmol} / 1$ and $0.25 \mathrm{mmol} / 1$ of calcium, glibenclamide failed to stimulate somatostatin release. In control perfusions where glibenclamide was absent throught the experiments, somatostatin release was not significantly affected whether tested at $2.75,0.64$ or $0.25 \mathrm{mmol} / 1$ calcium (Fig. 1).

\section{Effects of insulin and somatostatin deficiency on glibenclamide-inhibited glucagon release}

The observation that at $0.64 \mathrm{mmol} / 1$ of calcium glibenclamide strongly inhibited glucagon release and simultaneously failed to stimulate somatostatin but elicited a well preserved insulin response, suggested that the insulin response could be responsible for the inhibition of glucagon release through a paracrine mechanism. Experiments were therefore performed to study the inhibitory effect on glucagon release under conditions where enhanced B-cell secretion was eliminated. Thus, perfusions were carried out at $0.64 \mathrm{mmol} / 1$ of calcium in pancreata from insulin-deficient alloxan-treated rats. Insulin deficiency was determined by constant hyperglycaemia $(>20 \mathrm{mmol} / 1)$ and weight loss from the day after injection. Diabetic rats injected with insulin gained weight from $219 \pm 12 \mathrm{~g}$ to $294 \pm 9 \mathrm{~g}(n=6, p<0.001)$ during the week of treatment prior to perfusion experi-
Table 1. Effects of extracellular calcium on glibenclamide-induced release of insulin, glucagon and somatostatin

\begin{tabular}{|c|c|c|c|c|}
\hline \multirow{2}{*}{$\begin{array}{l}\text { Hormone } \\
\text { release }\end{array}$} & \multicolumn{4}{|c|}{ Concentration of $\mathrm{Ca}^{2+}$ in the perfusion medium } \\
\hline & $\begin{array}{l}2.75 \\
(n=6)\end{array}$ & $\begin{array}{l}1.19 \\
(n=6)\end{array}$ & $\begin{array}{l}0.64 \\
(n=6)\end{array}$ & $\begin{array}{l}0.25 \\
(n=8)\end{array}$ \\
\hline \multicolumn{5}{|c|}{ Insulin $(\mu \mathrm{U})$} \\
\hline $0-5 \mathrm{~min}$ & $1420 \pm 121$ & $1575 \pm 240$ & $2744 \pm 442^{a b}$ & $3039 \pm 312^{\mathrm{a}, \mathrm{b}}$ \\
\hline $6-20 \mathrm{~min}$ & $2114 \pm 188$ & $2225 \pm 1017$ & $2224 \pm 373$ & $3891 \pm 308^{\mathrm{ac}}$ \\
\hline \multicolumn{5}{|c|}{ Glucagon (pg) } \\
\hline $0-5 \mathrm{~min}$ & $-282 \pm 151$ & $-2514 \pm 349^{a}$ & $-3327 \pm 301^{a}$ & $3295 \pm 782^{\mathrm{a}, \mathrm{b}, \mathrm{c}}$ \\
\hline $6-20 \mathrm{~min}$ & $-1448 \pm 581$ & $-12752 \pm 2337^{a}$ & $-18850 \pm 1439^{a}$ & $-7673 \pm 1120^{a, b, c}$ \\
\hline \multicolumn{5}{|c|}{ Somatostatin (pg) } \\
\hline $0-5 \min$ & $138 \pm 30$ & $42 \pm$ & $-6 \pm 5^{\mathrm{a}, \mathrm{b}}$ & $4^{\mathrm{a}, \mathrm{b}}$ \\
\hline $6-20 \mathrm{~min}$ & $1267 \pm 109$ & $278 \pm$ & $0 \pm \quad 30^{\mathrm{a}} \mathrm{b}$ & $26 \pm 13^{\mathrm{a}, \mathrm{b}}$ \\
\hline
\end{tabular}

Results (means \pm SEM) are derived from Figure 1. The release of hormones is expressed a the integrated response (basal secretory rates subtracted) for the first phase, $0-5 \mathrm{~min}$, and second phase, $6-20 \mathrm{~min}$, of the test period during which glibenclamide was present.

a $p<0.05$ vs $2.75 \mathrm{mmol} / 1$ calcium; ${ }^{\mathrm{b}} p<0.05$ vs $1.19 \mathrm{mmol} / 1$ calcium; ${ }^{\mathrm{c}} p<0.05$ vs $0.64 \mathrm{mmol} / \mathrm{I}$ calcium

ments. The mean blood glucose concentration in these animals was $5.4 \pm 0.2 \mathrm{mmol} / 1 \quad(n=6)$ during the last 5 days of insulin treatment, and $5.1 \pm 1.1 \mathrm{mmol} / 1$ at the time of killing.

The pancreatic content of glucagon was similar in pancreata from non-diabetic, untreated and insulintreated diabetic rats $(3.94 \pm 0.38,3.88 \pm 0.36$ and $3.39 \pm$ $0.15 \mu \mathrm{g} /$ pancreas; $n=6$ ). The somatostatin content was slightly higher in glands from the untreated diabetic animals $(1.26 \pm 0.09 \mu \mathrm{g} /$ pancreas $)$ than from nondiabetic and insulin-treated diabetic rats $(0.79 \pm 0.05$ and 
A
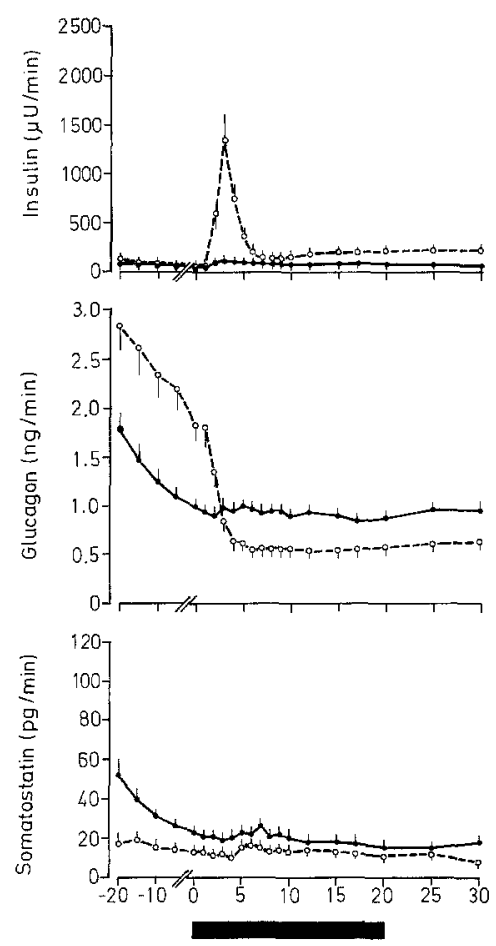

B

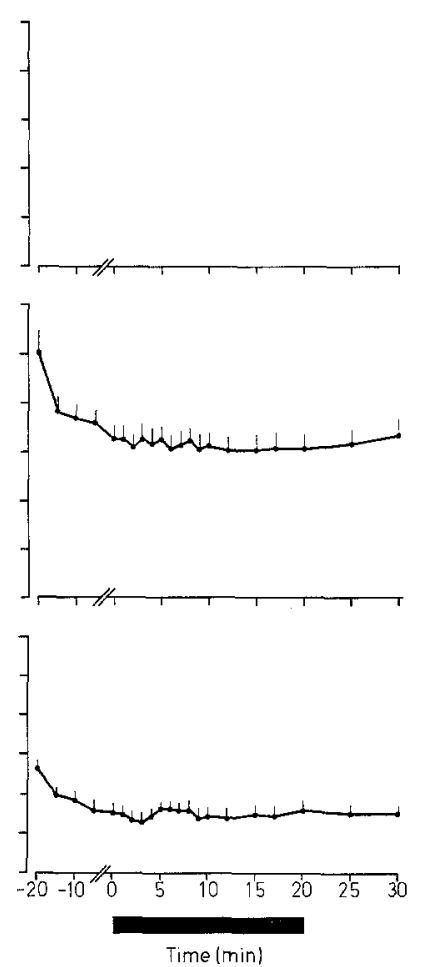

C

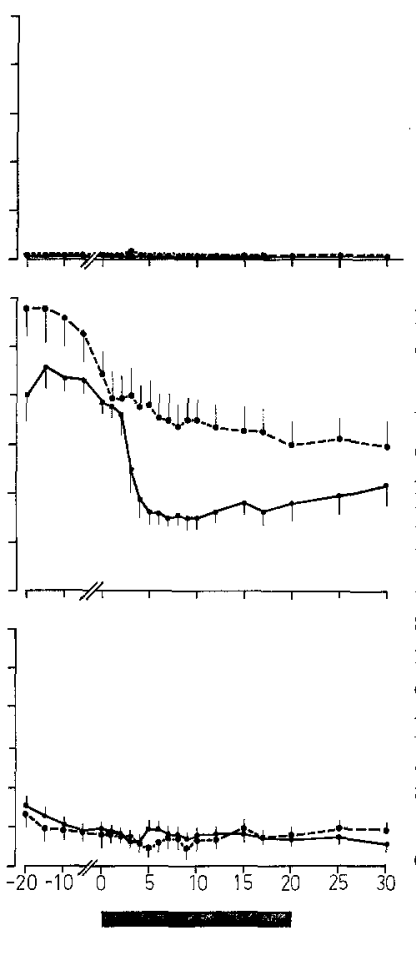

Fig. 2. Glibenclamide-induced hormone responses in pancreata from alloxan-diabetic rats perfused at a low calcium level $(0.64 \mathrm{mmol} / 1)$. Glibenclamide $(1 \mu \mathrm{g} / \mathrm{ml})$ was added during $\min 0-20(\mathrm{C})$. A Results from untreated diabetic rats $(\bullet)$; for comparison the response to glibenclamide in pancreata from normal rats is presented $(0--0)$. The latter experiments are identical with those given in Fig. 1. B Results from pancreata of diabetic rats where $24 \mathrm{U} / \mathrm{l}$ of insulin was present throughout the perfusion. C Results from diabetic rats treated with insulin in vivo $(\longrightarrow)$ ). Also included is the hormone release when pancreata isolated from the same group of rats were perfused in the absence of glibenclamide ( Mean \pm SEM of 6-7 perfusions in each group of animals
Table 2. Glibenclamide-induced hormone responses in diabetic pancreata perfused at a low calcium level

\begin{tabular}{|c|c|c|c|}
\hline $\begin{array}{l}\text { Hormone } \\
\text { release }\end{array}$ & $\begin{array}{l}\text { Diabetic rats } \\
\text { untreated }\end{array}$ & $\begin{array}{l}\text { Diabetic rats }+ \\
\text { insulin in vitro }\end{array}$ & $\begin{array}{l}\text { Diabetic rats }+ \\
\text { insulin in vivo }\end{array}$ \\
\hline \multicolumn{4}{|c|}{ Insulin $(\mu U)$} \\
\hline $0-5 \mathrm{~min}$ & $112 \pm 40$ & - & $159 \pm 55$ \\
\hline $6-20 \mathrm{~min}$ & $253 \pm 89$ & - & $68 \pm 31^{\mathrm{a}}$ \\
\hline \multicolumn{4}{|c|}{ Glucagon (pg) } \\
\hline $0-5 \mathrm{~min}$ & $-179 \pm 143$ & $-129 \pm 105$ & $-1828 \pm 685^{\mathrm{a}}$ \\
\hline $6-20 \mathrm{~min}$ & $-1191 \pm 509$ & $-1326 \pm 1039$ & $-14155 \pm 2502^{a}$ \\
\hline \multicolumn{4}{|c|}{ Somatostatin (pg) } \\
\hline $0-5 \min$ & $-12 \pm 10$ & $-10 \pm \quad 7$ & $-15 \pm$ \\
\hline $6-20 \mathrm{~min}$ & $-52 \pm 43$ & $-4 \pm 37$ & $-29 \pm \quad 24$ \\
\hline
\end{tabular}

Results (mean \pm SEM of 6-7 experiments in each group) are derived from Figure 2 and expressed as in Table 1. Perfusions were performed with $0.64 \mathrm{mmol} / 1$ calcium present throughout the experiments.

${ }^{a} \mathrm{p}<0.05$ vs untreated diabetic rats

$0.91 \pm 0.07 \mu \mathrm{g} /$ pancreas; $n=6, p<0.05$ ). The total insulin content was almost ten times higher after insulin treatment than in the untreated condition $(375.0 \pm 86.1$ vs. $39.6 \pm 7.7 \mathrm{mU} /$ pancreas; $n=6, p<0.01$ ). This increased content was, however, only $15 \%$ of that of pancreata from non-diabetic rats $(2.68 \pm 0.26 \mathrm{U} /$ pancreas; $n=12$ ).

Insulin. The insulin response to glibenclamide was small and insignificant in pancreata from both untreated and insulin-treated diabetic rats (Fig. 2A, C, Table 2).

Glucagon. Glibenclamide failed to exert a suppressive effect on glucagon release in pancreata from untreated diabetic rats (Fig. 2A, Table 2). Addition of a high concentration of porcine insulin $(24 \mathrm{U} / 1)$ to the perfusate did not restore a suppressive action (Fig. 2 B). However, when glibenclamide was perfused in pancreata from insulin-treated rats (Fig. 2C), the compound strongly inhibited glucagon release $(-18810 \pm 1577 \mathrm{pg} / 20 \mathrm{~min})$ as compared to control experiments where pancreata were perfused with basal medium only $(-9478 \pm 1568 \mathrm{pg} /$ $20 \min ; n=6, p<0.01$ ).

Somatostatin. As expected from the results from nondiabetic pancreata, glibenclamide-induced somatostatin release was also totally abolished in diabetic pancreata at a calcium concentration of $0.64 \mathrm{mmol} / 1$. Insulin treatment in vitro or in vivo did not affect this unresponsiveness (Fig. 2).

\section{Effects of calcium levels on tolazamide-induced hormone release}

Insulin. Tolazamide induced a similar, biphasic insulin response at $2.75 \mathrm{mmol} / 1$ and $0.64 \mathrm{mmol} / 1$ of calcium (Fig.3). The second phase was, however, only $30 \%$ of that elicited by glibenclamide ( $607 \pm 92$ vs $2114 \pm 188$ $\mu \mathrm{U} / 15 \mathrm{~min} ; p<0.001)$. Furthermore, in contrast to glibenclamide-induced release, the secretion decreased to pre-stimulatory rate after omission of tolazamide.

Glucagon. At both calcium concentrations, tolazamide exerted effects on glucagon release (Fig. 3) which were quantitatively and qualitatively identical to the effects by glibenclamide reported above. Thus, tolazamide in- 


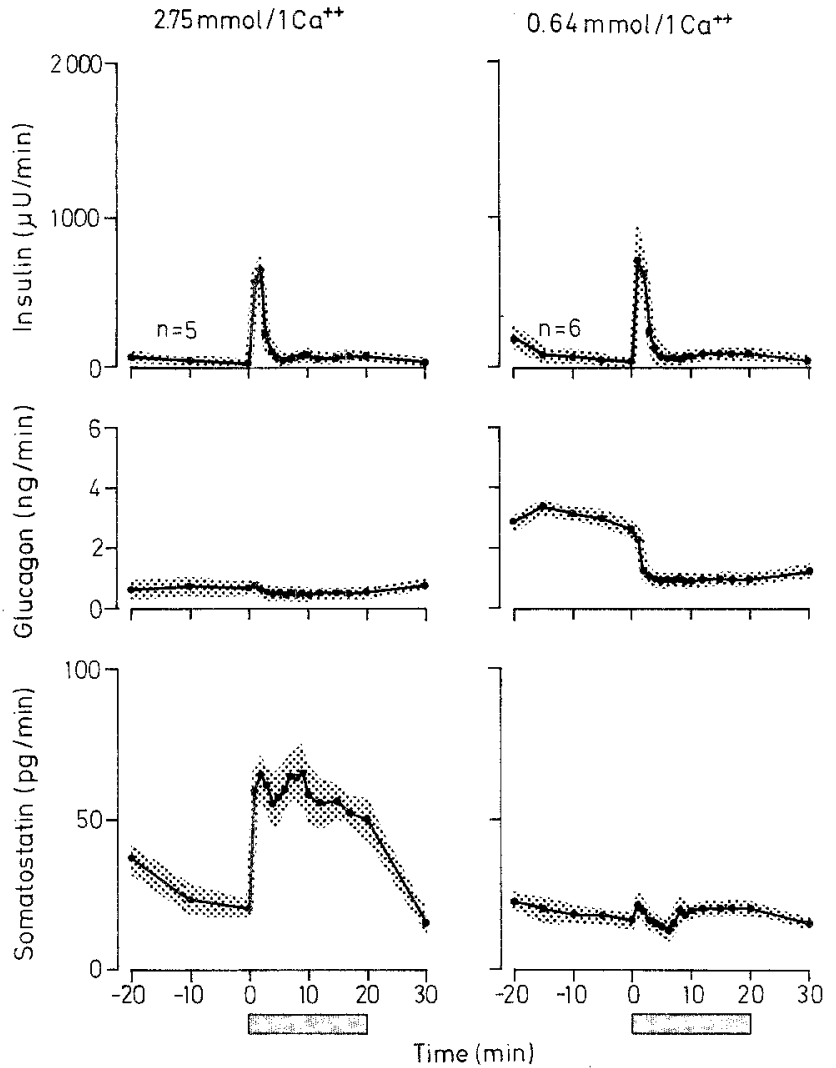

Fig. 3. Effects of different extracellular concentrations of calcium on the pancreatic hormone responses to tolazamide. Tolazamide $(10 \mu \mathrm{g} /$ $\mathrm{ml}$ ) was added during min $0-20$. Mean \pm SEM of the respective number of experiments given in the Figure. SEM is indicated by the shaded areas

hibited the secretion rate of glucagon at $0.64 \mathrm{mmol} / \mathrm{I}$ calcium by approximately 60 percent.

Somatostatin. At $2.75 \mathrm{mmol} / 1$ of calcium, tolazamide stimulated somatostatin secretion three-fold (Fig. 3). After omission of the drug the secretion returned to prestimulatory levels. At $0.64 \mathrm{mmol} / 1$ of calcium, tolazamide did not significantly affect the release of somatostatin.

\section{Discussion}

Concerning B- and D-cell secretion, the present study extends in more detail our recent report of a different calcium dependency of glibenclamide-stimulated secretion in the perfused rat pancreas [16]. Thus, a stepwise reduction of the extracellular calcium concentration promoted an enhanced B-cell response to the sulfonylurea, whereas the D-cell response was gradually suppressed and absent at $0.64 \mathrm{mmol} / 1$ or lower calcium levels. As to the glucagon-producing A cell, the interaction between calcium and glibenclamide was more complex. A decrease of the calcium concentration to 1.19 or $0.64 \mathrm{mmol} / 1$ caused an enhanced basal glucagon secretion, which was then markedly inhibited by glibenclamide. Needless to say, this suppression could not be mediated via a stimulation by the drug of endogenous somatostatin release. Thus, the present data do not favour the idea that glibenclamide-mediated suppression of glucagon release is due to a paracrine action by somatostatin on the A cells $[3,15,24]$.

Although glibenclamide inhibited glucagon secretion at $0.64 \mathrm{mmol} / 1$ calcium in the absence of a stimulated somatostatin release, our first series of experiments did not exclude a suppression of glucagon by a paracrine interaction between B and A cells. Hence, we repeated perfusions with glibenclamide at $0.64 \mathrm{mmol} / 1$ calcium in insulin-deprived pancreata from alloxandiabetic rats. To avoid the short-term interference reported between alloxan and the secretion of glucagon $[25,26]$ and somatostatin $[26,27]$, the animals were used for perfusions not earlier than 14 days after injection with alloxan. In our animals, like in other studies using alloxan- and streptozotocin-diabetic rats [28, 29], basal glucagon release from the perfused pancreata was lower than from glands of non-diabetic rats. The loss of a suppressive effect by glibenclamide on glucagon release in pancreata from the alloxan-treated rats would at first glance be compatible with a paracrine role for the endogenous insulin secretion induced by sulfonylurea. However, insulin treatment of the alloxan-diabetic rats to achieve normoglycaemia during 1 week before perfusion experiments restored the glibenclamide-induced suppression of glucagon secretion. From these data it can be concluded that glibenclamide exerts a direct inhibitory action on the A cell at a low calcium concentration. At $2.75 \mathrm{mmol} / 1$ calcium glibenclamide did not significantly inhibit glucagon secretion. It cannot be excluded that this lack of suppression could be due to the low basal secretion rate of glucagon present during the equilibration period preceding glibenclamide.

Normoglycaemia achieved by long-term insulin treatment of diabetic animals appears to be a prerequisite for the direct suppressive effect by the sulfonylurea on glucagon. It is not clear to which extent hyperglycaemia, insulinopenia and other metabolic aberrations associated with the diabetic state play a role in establishing insensitivity of the A cell. The present results do not support a direct effect of insulin, since this hormone, when added in vitro, did not restore suppressibility. Previous results give some indications of a role for hyperglycemia per se. It was demonstrated that ambient glucose profoundly influences glibenclamide-induced effects on glucagon secretion. When tested in the absence of glucose, and at normal calcium concentration, glibenclamide suppressed glucagon secretion, whereas this effect was not seen after the addition of glucose $[3,16]$. Hence, at least in some experimental situations, glucose attenuates a suppressive effect of glibenclamide on glucagon secretion. In this context it is also of interest that our findings are analogous to recent observations that chronic hyperglycaemia leads to glucose "blindness" of A cells, i.e. a failure of glucose to inhibit glucagon secretion $[30,31]$. However, the extent 
to which the present defect is related to that of glucose "blind ness" has not been investigated here.

The mechanisms by which sulfonylureas interact with islet hormone secretion have hitherto been studied extensively only in normal pancreatic islets, which consist of a majority of B cells [32]. Available data indicate that the insulin-releasing action is initiated by the binding of sulfonylurea to the plasma membrane of the $B$ cells, [33]. Thus, most sulfonylureas bind rapidly and selectively to membranes of B cells. Glibenclamide, however, also accumulates in the cells [33]. The differences in uptake could explain the protracted effects of glibenclamide, but not of tolazamide, after omission of the respective drug from the perfusate. It should be stressed that this does not indicate more than one mode of action in common for all sulfonylureas [33], since the nature of effects on pancreatic hormone secretion by glibenclamide and tolazamide were similar.

The present study demonstrates that sulfonylureas exert both stimulatory and inhibitory effects on glucagon secretion. The precise mechanisms behind these divergent actions are not known. However, available evidence suggests that both a stimulatory and an inhibitory effect of sulfonylurea on glucagon release can be secondary, at least in part, to sulfonylurea-induced alterations in calcium fluxes. Thus, the compounds induce uptake of ${ }^{45} \mathrm{Ca}^{++}$in islets and depolarize islet $\mathrm{B}$ cells, thereby allowing $\mathrm{Ca}^{++}$influx, at least in this type of cell [33]. Furthermore, glucagon secretion is diphasically dependent on the extracellular concentration of calcium. At very low concentrations of extracellular calcium (such as those achieved by addition of EGTA), addition of calcium stimulates glucagon secretion, whereas further addition of this ion inhibits secretion [34]. This dose-response pattern bears resemblance to the influence of glibenclamide on glucagon secretion in the present experiments. Glibenclamide-induced stimulation was thus prompt and apparent at low calcium $(0.25 \mathrm{mmol} / \mathrm{l})$, whereas the inhibitory effects on secretion were seen at higher extracellular calcium. The present control perfusions without glibenclamide at $0.25 \mathrm{mmol} / 1$ calcium indicate that the decline in glucagon release after the transient stimulation is time-dependent and not due to glibenclamide.

In previous experiments we used another protocol to study the interactions of calcium, sulfonylurea and glucose on glucagon secretion. Glucagon secretion was stimulated by a switch to calcium deficiency, and this response was further enhanced by the concomittant addition of glibenclamide [17]. In these experiments, the stimulatory effect of glibenclamide was more marked and prolonged than in the present experiments at the same concentration of calcium $(0.25 \mathrm{mmol} / \mathrm{l})$. The differences with regard to conditions during pre-perfusion may explain the partial difference in the effect of glibenclamide in the previous and the present series of experiments. The length of pre-perfusion without calcium has indeed been shown to significantly influence A cell responsiveness [35]. However, the mechanisms behind this influence remain to be elucidated.

Acknowledgements. This study was supported by the Swedish Medical Research Council (grants no 00034 and 04540), the Nordic Insulin Foundation, the Swedish Diabetes Association, the Magnus Bergvall Foundation, the Åke Wiberg Foundation, Funds of the Karolinska Institute and Osterman Foundation.

\section{References}

1. Ipp E, Dobbs RE, Arimura A, Vale W, Harris V, Unger RH (1977) Release of immunoreactive somatostatin from the pancreas in response to glucose, amino acids, pancreozymine-cholecystokinin, and tolbutamide. J Clin Invest 60: 760-765

2. Samols E, Weir GC, Ramseur R, Day JA, Patel YC (1978) Modulation of pancreatic somatostatin by adrenergic and cholinergic agonism and by hyper- and hypoglycemic sulfonamides. Metabolism 27 (Suppl 1): 1219-1221

3. Efendić S, Enzmann F, Nylén A, Uvnäs-Wallensten $K$, Luft $R$ (1979) Effect of glucose/sulfonylurea interaction on release of insulin, glucagon and somatostatin from isolated perfused rat pancreas. Proc Natl Acad Sci USA 76: 5901-5904

4. Aguilar-Parada E, Eisentraut AM, Unger RH (1969) Effect of HB419 induced hypoglycemia on pancreatic glucagon secretion. Horm Metab Res 1 (Suppl): 48-50

5. Pek S, Fajans SS, Floyd JC, Knoph RF, Conn JW (1972) Failure of sulfonylureas to suppress plasma glucagon in man. Diabetes 21: 216-222

6. Kajinuma H, Kuzuya T, Ide T (1974) Effects of hypoglycemic sulfonamides on glucagon and insulin secretion in ducks and dogs. Diabetes 23: 412-417

7. Loubatières AL, Loubatières-Mariani MM, Alric R, Ribes G (1974) Tolbutamide and glucagon secretion. Diabetologia 10: 271-276

8. Samols E, Harrison J (1976) Intraislet negative insulin-glucagon feedback. Metabolism 25 (Suppl 1): 1443-1447

9. Samols E, Tyler JM, Mialhe P (1969) Suppression of pancreatic glucagon release by the hypoglycemic sulfonylureas. Lancet 1 : 174-176

10. Laube H, Fussganger R, Goberna K, Schröder K, Straub K, Sussman K, Pfeiffer EF (1971) Effects of tolbutamide on insulin and glucagon secretion of the isolated perfused rat pancreas. Horm Metab Res 3: 238-242

11. Ohneda A, Sato M, Matsuda K, Itabashi H, Horigome K, Chiba M, Yamagata S (1974) Suppression of pancreatic glucagon secretion by tolbutamide in dogs. Horm Metab Res 6: 478-482

12. Grodsky GM, Epstein GH, Fanska R, Karam JH (1977) Pancreatic action of the sulfonylureas. Fed Proc 36: 2714-2719

13. Luyckx AS (1983) Pharmacologic compounds affecting glucagon secretion. In: Lefèbvre PJ (ed) Glucagon II. Handbook of experimental pharmacology, Vol66/II. Springer, Berlin Heidelberg New York, pp 175-177

14. Kadowaki S, Taminato T, Chiba T, Nozawa M, Fujita T, Norman AW (1983) Effect of tolbutamide on insulin, glucagon and somatostatin release from the diabetic rat pancreas with special reference to glucose concentration. Endocrinology 122: 2187-2192

15. Efendić S, Enzmann F, Nylén A, Uvnäs-Wallensten $K$, Luft $R$ (1980) Sulphonylurea (glibenclamide) enhances somatostatin and inhibits glucagon release induced by arginine. Acta Physiol Scand 108: 231-233

16. Efendić S, Grill V, Nylén A, Östenson C-G (1982) Difference in calcium dependendy of insulin, glucagon and somatostatin secretion in response to glibenclamide in perfused rat pancreas. Diabetologia $22: 475-479$ 
17. Grill V, Nylén A, Östenson C-G, Efendić S (1984) Glibenclamide stimulates and glucose inhibits glucagon release induced by calcium deprivation. Diabetes 33: 505-509

18. Östenson C-G, Grill V, Nylén A, Efendić S (1983) Modulation by IBMX, fasting and experimental diabetes of glibenclamide-induced islet hormone release from the perfused rat pancreas. Diabète et Métabolisme 9:58-65

19. Rasch R (1979) Control of blood glucose levels in the streptozotocin diabetic rat using a long-acting heat-treated insulin. Diabetologia 16: $185-190$

20. Loubatières AL, Mariani MM, Ribes G, DeMalbosc H, Chapal J (1969) Étude expérimentale d'un nouveau sulfamide hypoglycémiant particulièrement actif, le HB 419 ou glibenclamide. Diabetologia $5: 1-10$

21. Umbreit WW, Burris RH, Stauffer JF (1957) In: Manometric techniques, vol 1. Burgess, Minneapolis, $\mathrm{p} 149$

22. Herbert V, Lau KS, Gottlieb CW, Bleicher SJ (1965) Coated charcoal immunoassay of insulin. J Clin Endocrinol Metab 25: 1375-1384

23. Faloona GR, Unger RH (1974) Radioimmunoassay technique. In: Jaffe BM and Behrman HE (eds) Methods of hormone radioimmunoassay, vol 1. Academic, New York, pp 324-326

24. Frankel BJ, Heldt AM, Grodsky GM (1982) Effects of $\mathrm{K}^{+}$and arginine on insulin, glucagon, and somatostatin release from the in vitro perfused rat pancreas. Endocrinology 110: 428-431

25. Östenson C-G (1980) Alloxan reversibly impairs glucagon release and glucose oxidation by pancreatic A2-cells. Biochem J 188: 201-206

26. Goto Y, Berelowitz M, Frohman LA (1981) Acute effects of alloxan and streptozotocin-induced insulin deficiency on somatostatin and glucagon secretion by the perfused isolated rat pancreaticoduodenal preparation. Diabetologia 20: 66-71

27. Grill V, Efendić S (1984) Abnormal D cell secretion in alloxandiabetes: influence by drug and aberrant metabolism. Am J Physiol 246: E483-E492

28. Pagliara AS, Stillings SN, Haymond MW, Hover BA, Matschinsky FM (1975) Insulin and glucose as modulators of the aminoa- cid-induced glucagon release in the isolated pancreas of alloxan and streptozotocin diabetic rats. J Clin Invest 55: 244-255

29. Matschinsky FM, Pagliara AS, Hover BA, Pace CS, Ferrendelli JA, Williams A (1976) Hormone secretion and glucose metabolism in islets of Langerhans of the isolated perfused pancreas from normal and streptozotocin diabetic rats. J Biol Chem 251: 6053-6061

30. Unger R, Aguilar-Parada E, Muller W, Eisentraut A (1970) Studies of alpha cell function in normal and diabetic subjects. J Clin Invest 49: 837 $\sim 848$

31. Gerich JE (1983) Glucose in the control of glucagon secretion. In: Lefèbvre PJ (ed) Glucagon II. Handbook of experimental pharmacology, vol 66/II. Springer, Berlin Heidelberg New York, pp 4-18

32. Hellerström C (1977) Growth pattern of pancreatic islets in animals. In: Volk BW, Wellman KF (eds) The diabetic pancreas. Plenum, New York, pp 61-97

33. Gylfe E, Hellman B, Sehlin J, Täljedahl I-B (1984) Interaction of sulfonylurea with the pancreatic B-cell. Experentia 40: 1126-1134

34. Lundqvist I, Fanska R, Grodsky GM (1976) Interaction of calcium and glucose on glucagon secretion. Endocrinology 99: $1304-1312$

35. Leclercq-Meyer V, Marchand J, Malaisse WJ (1976) The role of calcium in glucagon release, interactions between glucose and calcium. Diabetologia 12: $531-538$

Received: 15 November 1985

and in revised form: 13 October 1986

Dr. Claes-Göran Östenson

Department of Endocrinology

Karolinska Hospital

S-104 01 Stockholm

Sweden 